\title{
Anti-inflammatory activity of Adenanthera pavonina L., Fabaceae, in experimental animals
}

\author{
Arzumand Ara, ${ }^{1}$ Mohammad Arifuzzaman, ${ }^{1}$ Chanchal K. Ghosh, ${ }^{2}$ Md. A. Hashem, ${ }^{1}$ \\ Mesbah U. Ahmad, ${ }^{1}$ Sitesh C. Bachar, ${ }^{3}$ Lutfun Nahar, ${ }^{4}$ Satyajit D. Sarker ${ }^{*, 5}$
}

\author{
${ }^{1}$ Department of Chemistry, Jahangirnagar University, Savar, 1342 Dhaka, Bangladesh, \\ ${ }^{2}$ Department of Gastroenterology, Sir Salimullah Medical College, Mitford, Dhaka, Bangladesh, \\ ${ }^{3}$ Department of Pharmaceutical Technology, Faculty of Pharmacy, University of Dhaka, 1000 Dhaka, Bangladesh, \\ ${ }^{4}$ Drug Discovery and Design Research Division, Department of Pharmacy, School of Applied Sciences, \\ University of Wolverhampton, MA Building, Wulfruna Street, Wolverhampton WV1 1LY, West Midland, UK, \\ ${ }^{5}$ Department of Pharmacy, School of Applied Sciences, University of Wolverhampton, MM Building, Molineux Street, \\ Wolverhampton WV1 1SB, West Midland, UK.
}

\begin{abstract}
RESUMO: "Atividade anti-inflamatória de Adenanthera pavonina L., Fabaceae, em animais experimentais". Adenanthera pavonina L, Fabaceae, conhecida na região de Bengala por "rakta kombol", é uma planta medicinal endêmica do sul da China e da Índia e amplamente difundida na Malásia, África Ocidental e Oriental, bem como na maioria das ilhas de ambas as regiões do Pacífico e Caribe. Esta planta tem sido utilizada na medicina tradicional para o tratamento da asma, febre, diarréia, gota, inflamações, reumatismo tumor, úlceras, e como tônico. Cascas secas e moídas de $A$. pavonina foi submetida a extração sucessiva com éter de petróleo (PE), diclorometano (DCM), acetato de etila (AcOEt) e metanol $(\mathrm{MeOH})$, e os extratos foram avaliados in vivo para atividade anti-inflamatória induzida por carragenina tendo como ensaio modelo de inflamação edema de pata em ratos.. Os extratos foram administrados por via oral em doses de 200 e $400 \mathrm{mg} / \mathrm{kg}$ de peso corporal, e foram observadas efeitos anti-inflamatórios de maneira dose-dependente, estatisticamente significativos $(p<0,001)$. O extrato metanólico $(400 \mathrm{mg} / \mathrm{kg})$ apresentou $37,10 \%(p<0,01)$ de inibição da inflamação na primeira hora do estudo e, o extrato DCM (400 mg/kg) apresentou $33,11 \%(p<0,001)$ na inibição da inflamação na terceira hora do estudo, que foi comparável ao resultado da substância de referência diclofenato de sódio. Os resultados deste estudo confirmaram alguns dos usos tradicionais desta planta medicinal.
\end{abstract}

Unitermos: Adenanthera pavonina, Fabaceae alt. Leguminosae, atividade anti-inflamatória, edema em ratos induzido por carragenanas.

ABSTRACT: Adenanthera pavonina L, Fabaceae alt. Leguminosae, Bengali name 'rakta kombol', is an Indian medicinal plant. It is endemic to Southern China and India, and widely naturalized in Malaysia, Western and Eastern Africa as well as in most islands of both the Pacific and Caribbean regions. This plant has been used in traditional medicine for the treatment of asthma, boil, diarrhoea, gout, inflammations, rheumatism, tumour and ulcers, and as a tonic. The dried and ground bark of A. pavonina L. was extracted, successively, with petroleum ether (PE), dichloromethane (DCM), ethyl acetate (EtOAc) and methanol (MeOH), and the resulting extracts were assessed in vivo for anti-inflammatory activity on carrageenaninduced rat hind paw oedema as a model of inflammation. The extracts were administered orally at the doses of 200 and $400 \mathrm{mg} / \mathrm{kg}$ body weight, and statistically significant $(p<0.001)$ anti-inflammatory effects were observed in a dose dependant manner. The $\mathrm{MeOH}$ extract (400 $\mathrm{mg} / \mathrm{kg}$ ) showed $37.10 \%(p<0.01)$ inhibition of inflammation at the first hour of the study and, the DCM extract $(400 \mathrm{mg} / \mathrm{kg})$ exhibited $33.11 \%(p<0.001)$ inhibition of inflammation at the third hour of the study which was comparable with that of reference standard drug dichlofenac sodium. The results of this study supported some of the traditional medicinal uses of this plant.

Keywords: Adenanthera pavonina, Fabaceae alt. Leguminosae, anti-inflammatory activity; Carrageenan-induced rat oedema. 


\section{INTRODUCTION}

Adenanthera pavonina L., Fabaceae alt. Leguminosae, commonly known in Bangladesh as 'rakta kombol', is an important medicinal plant from the 'Indian subcontinent'. This species is endemic to Southern China and India, and widely naturalized in Malaysia, Western and Eastern Africa as well as in most islands of both the Pacific and Caribbean regions (Balogun \& Fetuga, 1985; GRIN Databases, 2009). While the wood of this plant has been used for decorative wood products, the fruits are consumed by local people (Benthall, 1946; Clark \& Thaman, 1993). Various parts of this plant have also been used in traditional medicine for the treatment of asthma, boil, diarrhoea, gout, inflammations, rheumatism, tumour and ulcers, and as a tonic (Watt \& Breyer-Brandwijk, 1962; Kirtikar \& Basu, 1981; Burkil, 1994; Dr Duke's, 2009). The seeds of this plant have been found to be effective in treating cardiovascular diseases during pregnancy. Previous phytochemical studies on this plant revealed the presence of various secondary metabolites including mainly flavonoids, steroids, saponins and triterpenoids (Chandra et al., 1982; Yeoh et al., 1984). The antibacterial, antifungal, antioxidant, cytotoxic and blood pressure reducing activities of the extracts of $A$. pavonina have recently been reported (Jayasinghe et al., 2006; Rodrigo et al., 2007; Adedapo et al., 2009). We now report on the in vivo anti-inflammatory activity of various extracts of the bark of $A$. pavonina in carragennaninduced rat oedema model.

\section{MATERIAL AND METHODS}

\section{General}

The solvents petroleum ether (PE), dichloromethane (DCM), ethyl acetate (EtOAc) and methanol $(\mathrm{MeOH})$ were of the BDH laboratory $(\mathrm{BDH})$ grade, dichlofenac sodium was supplied by Square Pharmaceutical Ltd, Bangladesh, and carrageenan and Tween- 80 were of pharmaceutical grade.

\section{Plant material}

The barks of Adenanthera pavonina L., Fabaceae, were collected from a mature plant from the Jahangirnagar University campus, Savar, Dhaka, Bangladesh, in March 2008. A voucher specimen representing this collection (accession $\mathrm{N}^{\text {o. }}$ DACB34196) was deposited in the National Herbarium of Bangladesh.

\section{Extraction}

The barks of $A$. pavonina were shade-dried, pulverized by a mechanical grinder and passed through a
60 mesh sieve to obtain fine powder, a portion $(1.0 \mathrm{~kg})$ of which was extracted, successively, with PE, DCM, EtOAc and $\mathrm{MeOH}(2 \mathrm{~L}$ each). All extracts were evaporated to dryness under reduced pressure. The yields of the PE, DCM, EtOAc and $\mathrm{MeOH}$ extracts were $2.1 \mathrm{~g}, 3.7 \mathrm{~g}, 2.5 \mathrm{~g}$ and $30.0 \mathrm{~g}$, respectively.

\section{Animals}

Long Evan rats of either sex (weighing 130$180 \mathrm{~g})$ were collected from the International Centre for Diarrhoeal Diseases and Research, Bangladesh (ICDDR, B). The animals were kept in polyvinyl cages under controlled room temperature $\left(25 \pm 2{ }^{\circ} \mathrm{C}\right)$ in the laboratory environment under $12 \mathrm{~h}$ dark and $12 \mathrm{~h}$ light cycle for seven days. The ICDDR, B formulated food pellets were supplied to the animals and water at libitum. Animals were fasted overnight and weighed before the experiment. The study involving rats was approved by the Ethical Review Committee (approval number: SCB090221) Biological Science, University of Dhaka, Bangladesh, and the experiments were carried out strictly in accordance with the guidelines provided by the World Health Organization.

\section{Assessment of anti-inflammatory activity: the carrageenan-induced oedema model}

The anti-inflammatory activity of the extracts of A. pavonina was measured by the carrageenan-induced rat paw oedema model (Winter et al., 1962). Experimental animals were randomly selected, irrespective of sexes, and divided into ten groups consisting of 5 rats in each group. The test compounds were administered orally to each group at 200 and $400 \mathrm{mg} / \mathrm{kg}$ body weight. After $1 \mathrm{~h}$ of treatment, acute inflammation was produced by sub-planter injection of $0.1 \mathrm{~mL}$ of $1 \%$ suspension of carrageenan in normal saline in the right hind paw of the rats. Another animal group was treated with dichlofenac sodium at a dose of $15 \mathrm{mg} / \mathrm{kg}$ per orally (p.o.) as a reference standard. The saline treated group was considered as control. The paw volume was measured plethysmometrically (Ugo Basile, Italy) at 1, 2, 3 and 4 $\mathrm{h}$ after the carrageenan injection. Results were expressed as percentage of inhibition of oedema calculated by the formula- $\left(1-\mathrm{V}_{\mathrm{t}} / \mathrm{V}_{\mathrm{c}}\right) \times 100$, where $\mathrm{V}_{\mathrm{t}}$ and $\mathrm{V}_{\mathrm{c}}$ are the mean paw volume in the treated and controlled groups, respectively.

\section{Statistical analysis}

Statistical analysis was performed using SPSS11.5 statistical Software for Windows. Experimental values were expressed as mean \pm SEM. Independent Sample t-test was carried out for statistical comparison. Statistical significance was considered to be indicated by a $p$ value $<0.05$ in all cases. 
Table 1. Anti-inflammatory effects of the extracts of the barks of Adenanthera pavonina L. on the carrageenan-induced rat paw oedema.

\begin{tabular}{|c|c|c|c|c|c|}
\hline \multirow{2}{*}{ Treatment } & \multirow{2}{*}{ Dose $\mathrm{mg} \mathrm{kg}^{-1}$} & \multicolumn{4}{|c|}{ Carrageenan-induced rat paw oedema Mean $\pm \mathrm{SEM}^{*}$} \\
\hline & & $+1 \mathrm{~h}$ & $+2 \mathrm{~h}$ & $+3 \mathrm{~h}$ & $+4 \mathrm{~h}$ \\
\hline Control & - & $99.20 \pm 6.902$ & $106.80 \pm 3.597$ & $119.60 \pm 4.812$ & $102.4 \pm 4.445$ \\
\hline $\begin{array}{c}\text { Dichlofenac } \\
\text { sodium }\end{array}$ & 15 & $\begin{array}{c}73.80 \pm 3.056 \\
(25.60)^{\mathrm{b}}\end{array}$ & $\begin{array}{c}75.20 \pm 2.746 \\
(29.59)^{\mathrm{c}}\end{array}$ & $\begin{array}{c}76.00 \pm 3.821 \\
(36.45)^{\mathrm{c}}\end{array}$ & $\begin{array}{c}70.20 \pm 3.734 \\
(31.45)^{c}\end{array}$ \\
\hline \multirow{2}{*}{ PE extract } & 200 & $\begin{array}{c}73.80 \pm 1.158 \\
(25.60)^{\mathrm{b}}\end{array}$ & $\begin{array}{c}83.60 \pm 2.943 \\
(21.72)^{\mathrm{b}}\end{array}$ & $\begin{array}{c}98.20 \pm 2.223 \\
(17.89)^{\mathrm{b}}\end{array}$ & $\begin{array}{c}80.40 \pm 1.806 \\
(21.48)^{\mathrm{b}}\end{array}$ \\
\hline & 400 & $\begin{array}{c}71.60 \pm 3.763 \\
(27.82)^{\mathrm{b}}\end{array}$ & $\begin{array}{c}82.60 \pm 3.750 \\
(22.66)^{\mathrm{b}}\end{array}$ & $\begin{array}{c}97.60 \pm 2.786 \\
(18.39)^{\mathrm{b}}\end{array}$ & $\begin{array}{c}78.40 \pm 2.315 \\
(23.44)^{\mathrm{b}}\end{array}$ \\
\hline \multirow{2}{*}{ DCM extract } & 200 & $\begin{array}{c}73.00 \pm 2.025 \\
(26.41)^{\mathrm{b}}\end{array}$ & $\begin{array}{c}76.60 \pm 2.600 \\
(28.28)^{\mathrm{c}}\end{array}$ & $\begin{array}{c}81.80 \pm 3.470 \\
(31.61)^{\mathrm{c}}\end{array}$ & $\begin{array}{c}77.20 \pm 3.382 \\
(24.61)^{\mathrm{c}}\end{array}$ \\
\hline & 400 & $\begin{array}{c}69.80 \pm 2.498 \\
(29.64)^{\mathrm{b}}\end{array}$ & $\begin{array}{c}72.80 \pm 2.332 \\
(31.84)^{\mathrm{c}}\end{array}$ & $\begin{array}{c}80.00 \pm 1.378 \\
(33.11)^{\mathrm{c}}\end{array}$ & $\begin{array}{c}73.00 \pm 3.647 \\
(28.71)^{\mathrm{c}}\end{array}$ \\
\hline \multirow{2}{*}{ EtOAc extract } & 200 & $\begin{array}{c}78.20 \pm 2.615 \\
(21.17)^{\mathrm{a}}\end{array}$ & $\begin{array}{c}91.80 \pm 3.292 \\
(14.04)^{\mathrm{a}}\end{array}$ & $\begin{array}{c}104.40 \pm 5.921 \\
(12.71)^{\mathrm{NS}}\end{array}$ & $\begin{array}{c}86.60 \pm 4.632 \\
(11.55)^{\mathrm{a}}\end{array}$ \\
\hline & 400 & $\begin{array}{c}70.80 \pm 3.967 \\
(28.63)^{\mathrm{b}}\end{array}$ & $\begin{array}{c}89.40 \pm 4.118 \\
(16.29)^{\mathrm{a}}\end{array}$ & $\begin{array}{c}104.20 \pm 5.774 \\
(12.88)^{\mathrm{NS}}\end{array}$ & $\begin{array}{c}85.80 \pm 6.461 \\
(16.21)^{\mathrm{NS}}\end{array}$ \\
\hline \multirow{2}{*}{$\mathrm{MeOH}$ extract } & 200 & $\begin{array}{c}68.60 \pm 2.768 \\
(30.85)^{\mathrm{b}}\end{array}$ & $\begin{array}{c}80.00 \pm 2.302 \\
(25.09)^{\mathrm{c}}\end{array}$ & $\begin{array}{c}95.00 \pm 2.000 \\
(20.57)^{\mathrm{b}}\end{array}$ & $\begin{array}{c}81.00 \pm 2.168 \\
(20.89)^{\mathrm{b}}\end{array}$ \\
\hline & 400 & $\begin{array}{c}62.40 \pm 5.862 \\
(37.10)^{\mathrm{b}}\end{array}$ & $\begin{array}{c}76.80 \pm 4.964 \\
(28.09)^{\mathrm{b}}\end{array}$ & $\begin{array}{c}89.00 \pm 4.494 \\
(25.59)^{\mathrm{b}}\end{array}$ & $\begin{array}{c}80.40 \pm 4.915 \\
(21.48)^{\mathrm{a}}\end{array}$ \\
\hline
\end{tabular}

*The number of animal was 5 in each group. Figure in parenthesis indicate percent inhibition in paw volume. The probability values were calculated using student's ' $t$ '-test: $\mathrm{a}<0.05, \mathrm{~b}<0.01, \mathrm{c}<0.001$, NS=Not significant.

\section{RESULTS AND DISCUSSION}

The extracts of the barks of $A$. pavonina were evaluated for anti-inflammatory activity using the carrageenan-induced rat paw oedema model at dose levels of 200 and $400 \mathrm{mg} / \mathrm{kg}$ body weight, where dichlofenac sodium was used as a positive reference standard (Table 1). The results showed that the PE fraction exhibited $25.6 \%$ and $27.8 \%$ inhibition of the paw oedema at the doses of 200 and $400 \mathrm{mg} / \mathrm{kg}$, respectively at the first hour of the study. The DCM fraction exhibited maximum inhibition at the third hour of the study with $31.61 \%$ and $33.11 \%$ inhibition at the doses of 200 and $400 \mathrm{mg} /$ $\mathrm{kg}$, respectively. The DCM extract exhibited significant $(p<0.001)$ inhibition of paw oedema at different time intervals. The EtOAc extraction also demonstrated the maximum inhibition $(28.63 \%)$ after the first hour of the study at the dose of $400 \mathrm{mg} / \mathrm{kg}$ body weight only. On the other hand the $\mathrm{MeOH}$ extract displayed maximum anti-inflammatory effect at the first hour with $30.85 \%$ and $37.1 \%$ inhibition at the doses of $200 \mathrm{mg} / \mathrm{kg}$ and $400 \mathrm{mg} / \mathrm{kg}$ body weight, respectively, but at the second and third hour, the effects were observed in decreasing pattern. Among the extracts, the DCM extract showed the maximum effect at the third hour of the experiment, whereas the $\mathrm{MeOH}$ extracts exhibited the maximum effect at the first hour of the study at $400 \mathrm{mg} / \mathrm{kg}$. Both these extracts exhibited the anti-inflammatory effect in a dose dependent manner.

The carrageenan induced paw oedema model is known to be sensitive to cyclooxygenase inhibition which has been used to evaluate the effect of non-steroidal antiinflammatory agents (Seibert et al., 1994; Appleton et al., 1995). The time response of oedema in rat is believed to be biphasic (Vinegar et al., 1969). The first phase which occurs between 0.5 to $2 \mathrm{~h}$ after injection of the fluogestic agent has been attributed to the release of histamine or serotonin. The second phase of the inflammatory reaction is caused by the release of bradykinin, protease, prostaglandin and lysosome (Crunkhorn \& Meacock, 1971; Di Rosa \& Willoughby, 1971). Therefore it can be assumed that the inhibitory effect of the $\mathrm{MeOH}$ extract on carrageenan induced inflammation could be due to the inhibition of histamine or serotonin. On the other hand, the maximum inhibitory activity of the DCM extract at the third hour of the study was due to the inhibition of the enzyme cyclooxygenase leading to the inhibition of prostaglandin synthesis.

The significant in vivo anti-inflammatory activities exhibited by the extracts of $A$. pavonina in the carrageenan-induced rat paw oedema model provide some scientific evidence in support of the traditional uses of this plant for treatment of various inflammatory conditions, e.g. gout, rheumatism and tumours. 


\section{ACKNOWLEDGEMENTS}

The authors are thankful to Prof. Mohammad Rahmatullah, Pro-Vice Chancellor, University of Development Alternative, Dhaka, Bangladesh, for provision of the facilities for biological experiments. Arzumand Ara is grateful to the University Grant Commission (UGC), Bangladesh, for the award of a fellowship.

\section{REFERENCES}

Adedapo ADA, Osude YO, Adedapo AA, Moody JO, Adeagbo AS, Olajide OA, Makinde JM 2009. Blood pressure lowering effect of Adenanthera pavonina seed extract on normotensive rats. Records Nat Prod 3: 82-89.

Appleton I, Tomlinson A, Mitchell JA, Willoughby DA 1995. Distribution of cyclooxygenase isoforms in murine chronic granulomatous inflamation. Implication for future anti-inflammatory therapy. $J$ Pathol 176: 413420.

Balogun AM, Fetuga BL 1985 Fatty acid composition of seed oils of some members of the Leguminosae Family. Food Chem 17: 175-182.

Benthall AP 1946. Trees of Calcutta and its neighborhood. Calcutta: Thacker Spink and Co.

Burkil HM 1994. The useful plants of west tropical Africa. London: Royal botanical gardens.

Chandra S, Verma M, Saxena H 1982. Triterpenoids of Adenanthera pavonina root. Int J Crude Drug Res 20: 165-167.

Clark WC, Thaman RR 1993. Agroforestry in the pacific islands: systems for sustainability. Tokyo: United Nations University Press.

Crunkhorn P, Meacock SC 1971. Mediators of the inflammation induced in the rat paw by carageenan. Br J Pharmacol 42: 392-402.

Di Rosa M, Willoughby DA 1971. Screens for anti-inflammatory drugs. J Pharm Pharmacol 23: 297-298.

Dr. Duke's Phytochemical and Ethnobotanical Databases 2009. Green Pharmacy Garden, Fulton. http:/www. arsgrin.gov/cgibin/duke/ethnobot.pl? ethnobot. taxon=Adenanthera\%20pavonina.

GRIN Databses 2009. USDA, ARS, National Genetic Resources Program.Germplasm Resources Information Network(GRIN) [Online Database], National Germplasm Resources Laboratory, Beltsville, Maryland. http:// www.ars-grin.gov/cgi-bin/npgs/html/taxon.pl?1440.

Jayasinghe PKIDE, Bandara BMR, Ekanayaka EWMA, Thevanesam V 2006. Screening for antimicrobial activity of Acronychia pedunculata (Ankenda) and Adenanthera Pavonina (Madatiya) against bacteria causing skin and wound infections in humans. P Peradeniya Univ Res Sessions-Sri Lanka 11: 105-105.

Kirtikar KR, Basu BD 1981. Indian medicinal plants. India: International book distributors.
Rodrigo SK, Jayasingha ULB, Bandara BMR 2007. Antifungal, antioxidant and cytotoxic activity of Acronychia pedunculata and Adenanthera pavonina. P Peradeniya Univ Res Sessions-Sri Lanka 12: 94-95.

Seibert K, Zhang Y, Leahy K, Hauser S, Masferrer J, Perkins $\mathrm{W}$, Lee L, Isakson P 1994. Pharmacological and biochemical demonstration of the role of cylooxygenae 2 in inflammation and pain. P Natl Acad Sci 91: 1201312017.

Vinegar R, Schreiber W, Hugo R 1969. Biphasic development of carrageenin edema in rats; J. Pharmacol Exp Ther 166: 96-103.

Watt JM, Breyer-Brandwijk MG 1962. The medicinal and poisonous plants of southern and eastern Africa. London: E and S Livingstone Ltd.

Winter CA, Risley EA, Nuss GW 1962. Carrageenan induced oedema in hind paw of the rat as an assay for antiinflammatory drugs. P Soc Exp Biol Med 111: 544-547.

Yeoh HH, Wee YC, Watson L 1984. Systematic variation in leaf amino acid compositions of leguminous plants. Phytochemistry 23: 2227-2229. 